Article

\title{
Electron-induced rapid crosslinking in supramolecular metal-peptide assembly and chemically responsive disaggregation for catalytic application
}

\author{
Zongyuan Wang a,b, Jiajun Wang a , Zeyu Sun a, Wenlong Xiang a, Chenyang Shen a, Ning Rui a , \\ Mingzhu Ding a, Yingjin Yuan a , Honggang Cui b,c,d,\#, Chang-jun Liu a,* \\ a Collaborative Innovation Center of Chemical Science and Engineering, School of Chemical Engineering and Technology, Tianjin University, Tianjin \\ 300072, China \\ b Department of Chemical and Biomolecular Engineering, and Institute for NanoBioTechnology, The Johns Hopkins University, 3400 North Charles Street, \\ Baltimore, Maryland 21218, United States \\ c Center for Nanomedicine, The Wilmer Eye Institute, Johns Hopkins University School of Medicine, 400 North Broadway, Baltimore, Maryland 21231, \\ United States \\ d Department of Oncology and Sidney Kimmel Comprehensive Cancer Center, The Johns Hopkins University School of Medicine, Baltimore, Maryland \\ 21205, United States
}

\section{A R T I C L E I N F}

\section{Article history:}

Received 17 May 2020

Accepted 21 June 2020

Published 5 March 2021

\section{Keywords:}

Metal

Peptide

Assembly

Responsive release

Reduction

Catalyst

\begin{abstract}
A B S T R A C T
The applications of supramolecular metal-peptide assemblies as catalyst or catalyst precursor have recent attracted increasing attentions. In this work, a fragment of the amyloid $\beta$-peptide, $\mathrm{NH}_{2}$-KLVFF-COOH, was assembled into nanofilms with encapsulated Pd, Pt and Au nanoparticles (NPs) via a one-step room temperature electron induction method. The effects of building block, intermolecular interaction, driving force and side-chain on the assembly were investigated. The assembly mechanism was thereby proposed. The crosslinking of peptide monomers results in mainly random and unordered structures. The obtained metal-peptide assemblies are extremely stable in water at neutral pH for long term. However, the metal NPs are able to be responsively released under basic and reductive conditions. The released NPs show a high activity to catalyze the reduction of 4-nitrophenol. The present studies on assembly mechanism and responsive release will be helpful for the design of organic skeletons and also for the future development of peptide stabilized metallic NPs with applications beyond catalysts.
\end{abstract}

(C) 2021, Dalian Institute of Chemical Physics, Chinese Academy of Sciences. Published by Elsevier B.V. All rights reserved.

\section{Introduction}

Supramolecular assemblies have been extensively explored for the production of prodrugs [1], sensors [2], and other functional materials for catalysis [3-5], purification [6] and tissue engineering [7]. In order to functionalize the supramolecular structures, the metal nanoparticles (NPs) or metal active sites have been widely introduced and co-assembled with organic scaffolds to build metallized nanomaterials, such as the metal NPs decorated peptide filaments [8,9], metallo-polymers [10],

\footnotetext{
* Corresponding author. E-mail: coronacj@tju.edu.cn

\# Corresponding author. E-mail: hcui6@jhu.edu

This work was supported by the National Natural Science Foundation of China (21621004 and 21536008) and the China Scholarship Council (201706250085).

DOI: 10.1016/S1872-2067(20)63655-5 | http://www.sciencedirect.com/science/journal/18722067 | Chin. J. Catal., Vol. 42, No. 3, March 2021
} 
metal loaded hydrogels and aerogels [11,12]. The common metallization strategies include self-assembly $[13,14]$, metal-organic coordination [15-19], polymerization [20-22], electron-induced assembly [23-26]. Among them, the electron-induced assembly, developed by our group, have been applied for the preparation of highly efficient and stable metal-peptide catalysts for the energy conversion and $\mathrm{CO}_{2}$ utilization [24,25,27]. This method has the advantages of simple (one-step), fast (within few minutes) and green (with no need of hazardous reducing agents), noticeably resulting in two-dimensional (2D) peptide nanofilms decorated with highly uniform metal NPs. Based on this electron induced assembly strategy, a highly conductive peptide nanofilm was formed in the EY(Eosin Y)/Pt-KLVFF/ $/ \mathrm{TiO}_{2}$ catalyst for the improvement in the photo-induced electron transfer [26]. Enhanced photocatalytic activity for water splitting and $\mathrm{CO}_{2}$ reduction has been achieved [26]. The peptide assembly can be also used to control the tendentious growth of Pt (111) facets on carbon black support, causing an enhanced electrocatalytic activity of oxygen reduction reaction [23]. Besides the benefit on electron transfer and crystal facet growth, the carbonized peptide nanofilms can stabilize the $\mathrm{Pd}-\mathrm{In}_{2} \mathrm{O}_{3}$ interface of $\mathrm{Pd} / \mathrm{In}_{2} \mathrm{O}_{3}$ catalyst to avoid the formation of PdIn alloy and provide more oxygen vacancies for $\mathrm{CO}_{2}$ activation in catalytic $\mathrm{CO}_{2}$ hydrogenation to methanol [28]. These studies have proven that the electron-induced assembly is a powerful tool of fabricating supramolecular catalysts with great potentials for other applications. However, the mechanism of the electron induced peptide-metal assembly is still not clear. It is very necessary to investigate the electron induced mechanism of the peptide-metal assembly for its promising extensive applications. In this work, noble metals (Pd, Pt and $\mathrm{Au}$ ) and a pentapeptide fragment of the amyloid $\beta$-peptide (KLVFF) were chosen as the precursors to form metal-peptide nanofilms. Careful control of the molar ratio and concentration of precursors can realize uniform metal NPs with ultra-small diameters (1-2 nm) to make a rational comparison of the catalytic performance. The building block of 2D assembled structures was investigated and found to be nanodisks, which is quite different from self-assembled peptide materials. Metal structures and functional groups of peptides were also investigated by the combination of experimental results and theoretical calculations, suggesting the surface properties of metal NPs have been changed and the hydrogen bonds provide the mainly intermolecular interaction between peptide monomers. Side chains of peptides are found to have a relevant role in the assembly process. The metal-peptide nanofilms were able to responsively release metal NPs under basic and reductive conditions and then catalyzed the reduction of 4-nitrophenol efficiently.

\section{Experimental}

\subsection{Synthesis of metal-peptide nanofilms}

Noble metal ions and peptides were mixed in water and placed in a quartz boat. The electron-induced assembly process was conducted at room temperature and ca. 200 Pa (Fig. S1).
Argon glow discharge plasma served as the electron source. It was generated with an AC square-wave-type voltage of $600 \mathrm{~V}$ at $100 \mathrm{~Hz}$. The applied power was about $18 \mathrm{~W}$. A very low flow rate of argon was applied to keep the vacuum. No effect of flow rate was found on the assembly at such low flow rate. Therefore the flow rate was not measured. The details of the glow discharge plasma can be found in our previous works [23-27]. Typically, after 10-min treatment of $\mathrm{Pd}\left(\mathrm{NO}_{3}\right)_{2}$ (0.5 mM, sigma-aldrich) and KLVFF (0.5 mM, Shanghai Science Peptide Biological Technology Co. Ltd., China, 98\%) aqueous solution, 2D $\mathrm{Pd}_{0.5}-\mathrm{P}_{0.5}$ nanofilm product was floating at the interface of argon gas and solution. The nanofilms were washed with deionized water and then lyophilized. $\mathrm{Pd}_{0.5}-\mathrm{P}_{0.5}, \mathrm{Pt}_{0.5}-\mathrm{P}_{0.5}$, $\mathrm{Au}_{0.01}-\mathrm{P}_{0.2}, \mathrm{Au}_{0.01}-\mathrm{P}_{0.2}$ and $\mathrm{M}_{0}-\mathrm{P}_{0.5}$ (metal-free) were prepared using the corresponding concentration $(\mathrm{mM})$ of the metal and peptide. $\mathrm{Pd}_{0.5} \mathrm{GGG}_{0.5}$ and $\mathrm{Pd}_{2} \mathrm{FF}_{1}$ were also prepared by changing peptide to GGG and FF (sigma-aldrich).

\subsection{Characterizations}

The X-ray diffraction (XRD) patterns of the samples were recorded on a Rigaku D/Max-2500 diffractometer at a scanning speed of $4^{\circ} / \mathrm{min}$ over the $2 \theta$ range of $5^{\circ}-80^{\circ}$. The diffractometer was equipped with a Ni-filtered $\mathrm{Cu} K_{\alpha}$ radiation source $(\lambda=$ $1.54056 \AA$ A). The X-ray photoelectron spectroscopy (XPS) analyses were performed with a Perkin Elmer PHI-1600 spectrometer using $\mathrm{Mg} K_{\alpha}(\mathrm{h} v=1486.6 \mathrm{eV})$ radiation. The binding energies were calibrated using the $\mathrm{C} 1 s$ peak $(284.6 \mathrm{eV})$ as a reference. Transmission electron microscopy (TEM) was conducted on a Philips Tecnai G2F20 system. The metal peptide nanofilms were deposited on a copper grid and observed after air drying. Scanning electron microscopy (SEM) was performed on an FEI Nanosem430 system after pasting a piece of samples on conductive tape and coating a thin layer of gold by using a K575XD ion sputter (QUORUM, UK). Fourier Transform Infrared (FTIR) spectra were obtained on a Thermo Nicolet's Nexus 870 system at room temperature and in air. The FTIR spectra were recorded with 32 scans and at a resolution of $4 \mathrm{~cm}^{-1}$. ${ }^{1} \mathrm{H}$-nuclear magnetic resonance $\left({ }^{1} \mathrm{H}-\mathrm{NMR}\right)$ spectra were recorded on a Bruker AVANCE III $400 \mathrm{~Hz}$ instruments using DMSO-D 6 ; for $\mathrm{D}_{2} \mathrm{O}$ exchanging, two drops of $\mathrm{D}_{2} \mathrm{O}$ were added into the DMSO-D 6 before test. Samples for atomic force microscopy (AFM) analysis were prepared by loading Pd-peptide nanofilms on a freshly peeled mica substrate and left to dry under ambient conditions before imaging. AFM images were recorded on a Multimode SPM and Nanoscope V controller (Veeco Instruments) in the tapping mode with a silicon cantilever. Thermogravimetric analysis and differential scanning calorimetry (TGA-DSC) analysis of the catalysts was carried out on a Netzsch STA 449 F3 system under a mixed gas atmosphere (total flow: $\left.25 \mathrm{~mL} / \mathrm{min}, \mathrm{O}_{2}: \mathrm{N}_{2}=1: 4\right)$ at a constant rate of $10{ }^{\circ} \mathrm{C} / \mathrm{min}$. The catalyst was loaded into an alumina crucible and heated from room temperature to $1000{ }^{\circ} \mathrm{C}$. Mass spectrometry was conducted by MALDI-ToF (Bruker Autoflex III MALDI-ToF instrument, Billerica, MA).

\subsection{Density functional theory (DFT) calculations}


DFT calculations were performed by using the DMol3 module in Material Studio [29-31]. The generalized gradient approximation (GGA) with Perdew-Burke-Ernzerhof (PBE) [32] was used to describe the exchange-correlation (XC) effects. The double numerical basis sets plus polarization functional (DNP) [29] was applied in the expanded electronic wave function. For all of the calculations, the optimization convergence in energy and force was set to $1.0 \times 10^{-5} \mathrm{Ha}$ and $2 \times 10^{-3} \mathrm{Ha} \AA^{-1}$, and the SCF convergence was set to $1.0 \times 10^{-6} \mathrm{Ha}$. Water is set as the reaction solvent.

\subsection{Catalytic hydrogenation reactions of 4-nitrophenol}

The excellent performances of the metal-peptide assemblies for photocatalytic water splitting to hydrogen and photocatalytic $\mathrm{CO}_{2}$ reduction [26] and for oxygen reduction reaction [23] have been reported previously. The Pd-peptide assembly was also mixed with $\mathrm{In}_{2} \mathrm{O}_{3}$ to avoid the formation of PdIn alloy for the preparation of $\mathrm{Pd} / \mathrm{In}_{2} \mathrm{O}_{3}$ catalyst with high activity towards hydrogenation of $\mathrm{CO}_{2}$ to methanol [28]. In this work, hydrogenation reaction of 4-nitrophenol was chosen as a model reaction for the evaluation of the metal-peptide assemblies. The reaction was conducted in aqueous solution at atmospheric pressure and room temperature $\left(22^{\circ} \mathrm{C}\right)$. Briefly, $1 \mathrm{mg}$ of nanofilm was added into $10 \mathrm{~mL}$ deionized water. $100 \mu \mathrm{L}$ of $50 \mathrm{mM}$ $\mathrm{NaBH}_{4}$ was quickly added and stirred for 20 min to ensure complete reduction and release of metal NPs. Then sufficient water was added to the obtained solution of $\mathrm{Pd}_{0.5}-\mathrm{P}_{0.5}(47 \mu \mathrm{L})$, $\mathrm{Pt}_{0.5}-\mathrm{P}_{0.5}(86 \mu \mathrm{L})$ or $\mathrm{Au}_{0.01}-\mathrm{P}_{0.2}(74 \mu \mathrm{L})$ to prepare a total volume of $0.5 \mathrm{~mL}$ catalyst solution. These values were selected to ensure the same mol amount of metal ( $5 \mathrm{~mol} \%)$. Next, $2.5 \mathrm{~mL}$ of 4-nitrophenol $(0.06 \mathrm{mM})$ and $\mathrm{NaBH}_{4}(60 \mathrm{mM})$ aqueous solution was freshly prepared and mixed with the $0.5 \mathrm{~mL}$ catalyst solution. The time dependent absorption spectra were recorded at $90 \mathrm{~s}$ intervals using a UV-2600 UV-vis spectrophotometer (Shimadzu Corporation).

\section{Results and discussion}

\subsection{Morphological and structural analysis}

The morphology of metal-peptide nanofilms was investigated. After assembly, washing and lyophilization, free-standing peptide nanofilms were successfully obtained, showing a soft, lightsome and flocculent 3D macroscopical structure (Fig. 1(a)). The color of $\mathrm{Pd}_{0.5}-\mathrm{P}_{0.5}, \mathrm{Pt}_{0.5}-\mathrm{P}_{0.5}$ and $\mathrm{Au}_{0.01}-\mathrm{P}_{0.2}$ is yellow, brown and reddish brown, respectively (insets of Fig. 1(b)-(d)). The SEM images showed their microscopic morphology of free-standing thin nanofilms, spanning dozens of microns in width. The TEM images of $\mathrm{Pd}_{0.5}-\mathrm{P}_{0.5}$, $\mathrm{Pt}_{0.5}-\mathrm{P}_{0.5}$ and $\mathrm{Au} 0.01-\mathrm{P}_{0.2}$ exhibit uniform metal NPs with diameters of $1.8 \pm 0.2,1.2 \pm 0.2$ and $1.5 \pm 0.2 \mathrm{~nm}$, respectively (Fig. 2). Wide range images in Fig. S2 proved metal NPs were only distributed on peptide films. The quite small size (less than $2 \mathrm{~nm}$ ) with high NPs density suggests the one-step assembly can efficiently control the growth of metal NPs through the combination of the electron reduction and peptide assistance.

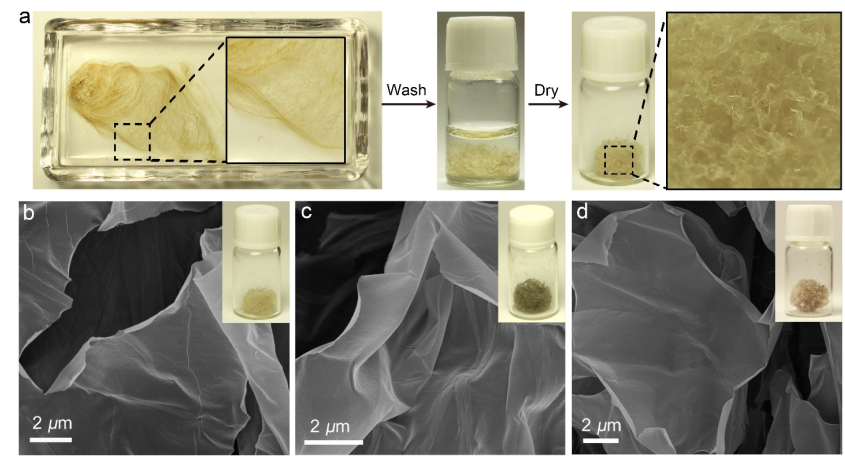

Fig. 1. Schematic synthesis and SEM images of the metal-peptide nanofilms. (a) The digital photos of $\mathrm{Pd}_{0.5}-\mathrm{P}_{0.5}$ nanofilm product; (b-d) the SEM images and digital photos (insets of b-d) of $\mathrm{Pd}_{0.5}-\mathrm{P}_{0.5}$ (b), $\mathrm{Pt}_{0.5}-\mathrm{P}_{0.5}$ (c) and $\mathrm{Au}_{0.01}-\mathrm{P}_{0.2}$ (d) nanofilms.

After morphological observation of metal-peptide nanofilms, we investigated the metallic state of metal NPs. The high-resolution TEM images (insets of Figs. 2(b), 2(e), 2(h), and S3) show the Pd, Pt and Au NPs with mainly (111) facet of zero-valent metal. The feature of (111) facet in electron-reduced noble-metal materials have been extensively reported $[23,26]$. XRD patterns of $\mathrm{Pd}_{0.5}-\mathrm{P}_{0.5}, \mathrm{Pt}_{0.5}-\mathrm{P}_{0.5}$ and $\mathrm{Au}_{0.01}-\mathrm{P}_{0.2}$ show a broad peak for amorphous organics at about $25^{\circ}$, which are the same with KLVFF powder (Fig. 3(a)). No metal peaks are observed due to the ultrafine NPs, corresponding to TEM results. The size of $\mathrm{Au}$ NPs increases to $3.6 \pm 0.7 \mathrm{~nm}$ in $\mathrm{Au}_{0.1}-\mathrm{P}_{0.5}$ that is synthesized by increasing $\mathrm{Au}$ ion concentration to $0.1 \mathrm{mM}$ (Fig. S4). The $\mathrm{Au}^{0}$ peaks at $2 \theta=38.2^{\circ}, 44.1^{\circ}, 64.9^{\circ}$ and $77.4^{\circ}$ are observed, assigned to the (111), (200), (220) and (311) reflections of the face-centered cubic (fcc) Au crystalline lattice (PDF\#65-2870). After increasing Pd and Pt concentrations to 2 $\mathrm{mM}$, the metal NPs still showed small sizes and no XRD signals, as reported in previous works $[23,28]$. The electrons in plasma have significant influence on the surface property of metal species [33-36]. The XPS is employed to characterize the chemical environment of metal species of the nanofilms (Fig. 3(b)-(d)). Full spectra showed in Fig. S5. $\mathrm{Pt}_{0.5}-\mathrm{P}_{0.5}$ shows two peaks at 71.9 and $75.2 \mathrm{eV}$, which can be assigned to $\mathrm{Pt}^{0}$. Au $\mathrm{Au}_{0.01}-\mathrm{P}_{0.2}$ shows two peaks at 83.3 and $87.0 \mathrm{eV}$, corresponding to $4 f_{7 / 2}$ and $4 f_{5 / 2}$ level of $\mathrm{Au}^{0}[37,38]$. As to $\mathrm{Pd}_{0.5}-\mathrm{P}_{0.5}$, the two peaks are located at 337.6 and $342.8 \mathrm{eV}$, corresponding to $3 d_{5 / 2}$ and $3 d_{3 / 2}$ level of PdO, respectively $[39,40]$. The surface palladium was detected mainly in the form of $\mathrm{PdO}(\mathrm{PdO} / \mathrm{Pd}=70 \% / 30 \%)$. The result indicates that a surface oxide layer is formed, possibly because Pd NPs combine with oxygen-containing groups of peptides. The TEM, XRD and XPS results prove Pd, Pt and Au ions are reduced to zero-valent during assembly, and a surface oxide layer formed on Pd NPs.

The metal loading amount was determined by TGA-DSC analysis, as shown in Fig. S6. The pure KLVFF powder is completely decomposed during the heating process under air, showing a mass loss of $99.4 \%$ at $750{ }^{\circ} \mathrm{C}$. $\mathrm{Pd}_{0.5}-\mathrm{P}_{0.5}, \mathrm{Pt}_{0.5}-\mathrm{P}_{0.5}$ and $\mathrm{Au}_{0.01}-\mathrm{P}_{0.2}$ nanofilms show a mass loss of $79.9 \%, 63.3 \%$ and $79.5 \%$, respectively. The final residues should be PdO, Pt and $\mathrm{Au}$ with approximately $0.4 \%-0.6 \%$ organic residues after the air calcination. Thus, the metal mass percent of $\mathrm{Pd}_{0.5}-\mathrm{P}_{0.5}$, 

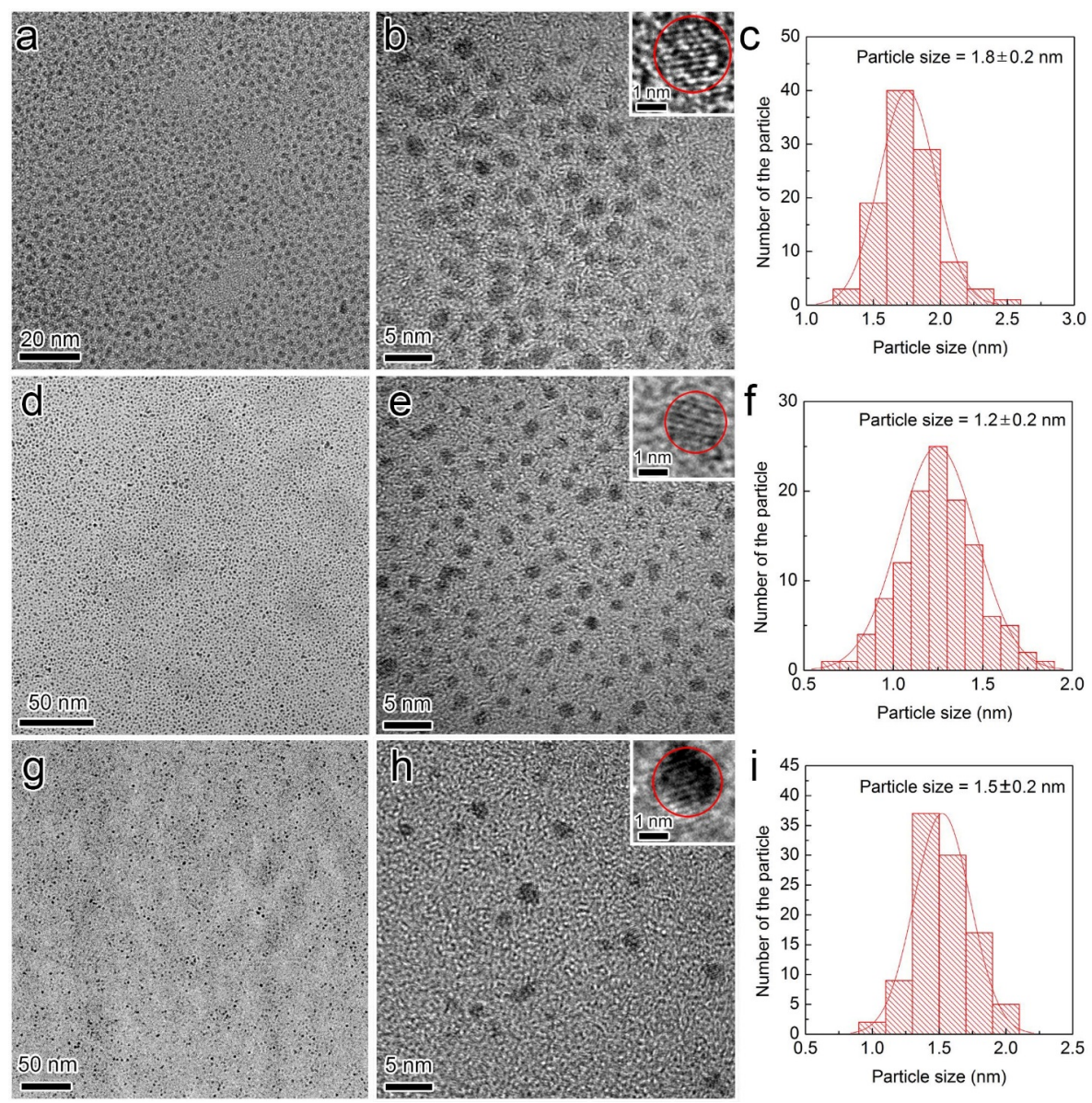

Fig. 2. TEM images and metal distributions of metal-peptide nanofilms: $\mathrm{Pd}_{0.5}-\mathrm{P}_{0.5}(\mathrm{a}-\mathrm{c}), \mathrm{Pt}_{0.5}-\mathrm{P}_{0.5}\left(\mathrm{~d}-\mathrm{f}\right.$ ) and $\mathrm{Au}_{0.01}-\mathrm{P}_{0.2}$ (g-i); the insets in (b,e,h) show the distances of crystal facets; (c), (f) and (i) are the statistical result of particle size.

$\mathrm{Pt}_{0.5}-\mathrm{P}_{0.5}$ and $\mathrm{Au}_{0.01}-\mathrm{P}_{0.2}$ nanofilms is approximately $17 \%, 17 \%$, and $20 \mathrm{wt} \%$, respectively.

\subsection{Assembly mechanism}

With an understanding of the morphology of the metal-peptide nanofilms, we next explored the assembly mechanism using $\mathrm{Pd}_{0.5}-\mathrm{P}_{0.5}$. The AFM images show the steric and surface information of $\mathrm{Pd}_{0.5}-\mathrm{P}_{0.5}$ nanofilm (Fig. 4). The height scan- ning results within a region of $20 \times 20 \mu \mathrm{m}^{2}$ show a film structure, which agrees with SEM (Fig. 4(a)). The height profile of the red-line section (Fig. 4(d)) shows the thickness of 1, 2, 3 and 4 layer is $21,39,58$ and $77 \mathrm{~nm}$, respectively, indicating the average thickness of $\mathrm{Pd}_{0.5}-\mathrm{P}_{0.5}$ film is $20.3 \pm 1.0 \mathrm{~nm}$. Then the synchronous height and phase scanning in a small area $(100$ $\mathrm{nm} \times 100 \mathrm{~nm}$ ) was performed to investigate the details of the film surface (Fig. 4(b) and 4(c)). The results show a smooth surface with a uniform phase distribution, suggesting the metal
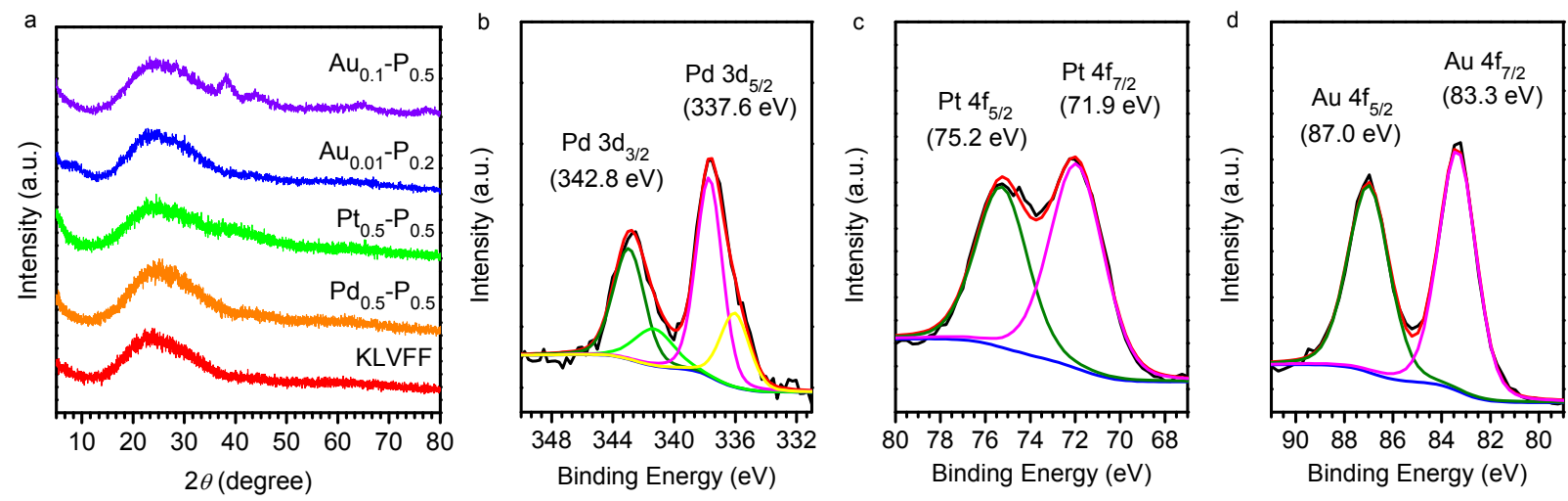

Fig. 3. (a) The XRD patterns of pure KLVFF, $\mathrm{Pd}_{0.5}-\mathrm{P}_{0.5}, \mathrm{Pt}_{0.5}-\mathrm{P}_{0.5}, \mathrm{Au}_{0.01}-\mathrm{P}_{0.2}$ and $\mathrm{Au}_{0.1}-\mathrm{P}_{0.5}$ samples; (b-d) the XPS spectra of Pd $3 d$, $\mathrm{Pt} 4 f$ and $A u 4 f$. 


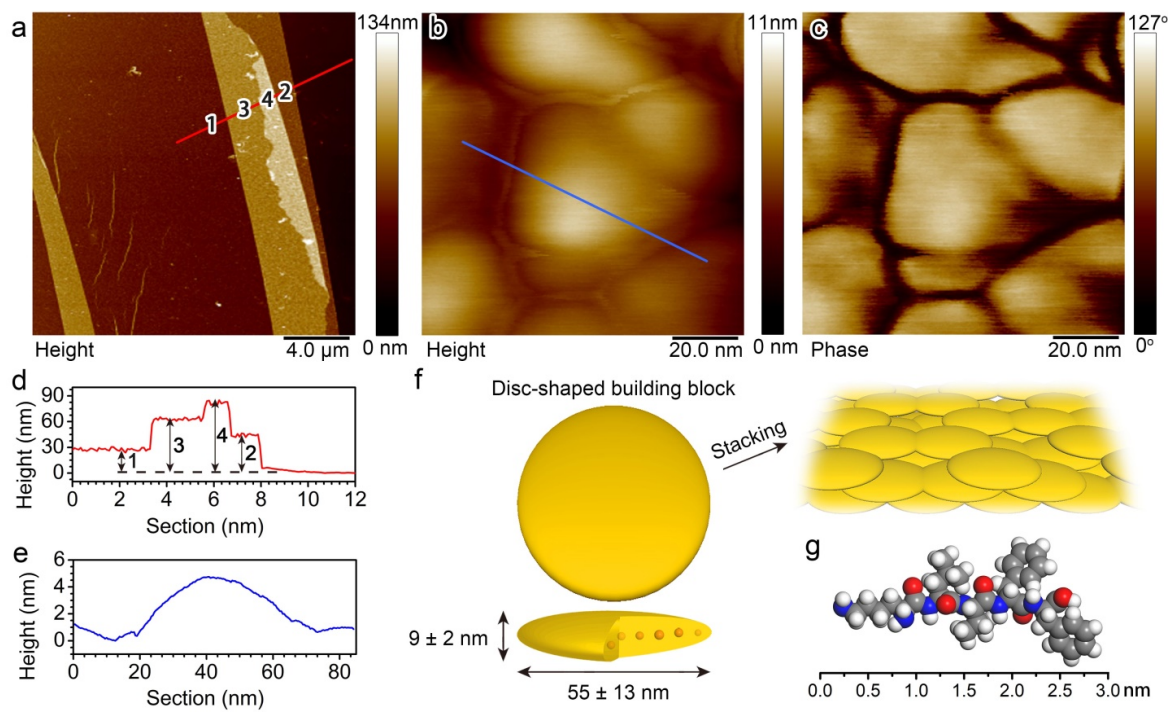

Fig. 4. The AFM images of $\mathrm{Pd}_{0.5}-\mathrm{P}_{0.5}$ nanofilms. AFM height (a,b) and phase (c) scanning images; (d,e) the height of the red-line and blue-line section in a and b, respectively; (f) schematic illustration of peptide nanofilms encapsulating metal NPs; (g) approximate geometric length of KLVFF estimated by Materials Studio.

NPs are encapsulated inside the film rather than decorated on the surface. The building blocks of nanofilms were found to be overlapped round or oval nanodiscs. The average diameter and thickness of the nanodiscs are $55 \pm 13$ and $9 \pm 2 \mathrm{~nm}$ (Fig. 4(e)), suggesting the nanodiscs are stacked up to 2-3 floors in one-layer film. Based on the observation, the illustration of metal-peptide assembly is shown in Fig. 4(f). Metal NPs with small size of 1-2 $\mathrm{nm}$ are encapsulated in disc-shaped building blocks (9 $\mathrm{nm}$ thickness) and stack to the nanofilm (20 nm thickness). The theoretically geometric size of KLVFF is approximately $3 \mathrm{~nm}$ in length (Fig. $4(\mathrm{~g})$ ). The thickness of nanodiscs $(9 \mathrm{~nm})$ exactly corresponds to the total length of two peptides $(3+3 \mathrm{~nm})$ and one Pd NP (1.8 $\mathrm{nm})$, suggesting a possible structure that the peptides encircle the metal NPs.

The AFM analysis clearly reveals the construction of metal-peptide nanofilms level by level: from monomers to disc-shaped building blocks, further to films. Next, we investigated the functional groups in nanofilms to understand the interaction between peptide monomers. The FTIR analysis was performed to investigate the functional groups after assembly (Fig. 5(a)-(c)). For KLVFF powders (Fig. 5(a)), the peaks at 3274 and $3088 \mathrm{~cm}^{-1}$ are assigned to $\mathrm{NH}$ stretching (amide A) and bending bands (amide B), respectively. Peaks at 3028, 2965, 2933 and $2874 \mathrm{~cm}^{-1}$ are assigned to the stretching vibrations of benzene rings, asymmetric $\mathrm{CH}_{3}$, asymmetric $\mathrm{CH}_{2}$ and symmetric $\mathrm{CH}_{3}$, respectively [41]. Highly ordered $\alpha$-helice and $\beta$-sheet structures present amide I bands at 1650-1660 and 1610-1640 $\mathrm{cm}^{-1}$, respectively [42,43]. Random-coil and turn structures present amide I bands at 1640-1650 and $1660-1685 \mathrm{~cm}^{-1}$, respectively [42,43]. The KLVFF powders with two overlapped peaks of 1639 and $1681 \mathrm{~cm}^{-1}$ yield a combined amide I feature of $\beta$-sheet, random-coil and turn structures, and the self-assembled KLVFF shows a blue-shifted $\beta$-sheet peak located at $1629-1633 \mathrm{~cm}^{-1}[25,41]$.

Then, FTIR spectra of the Pd-peptide assembly were investigated under increasing reaction time and Pd concentration. A broad peak appears and significantly increases in the region of $-\mathrm{OH}$ groups at $3486 \mathrm{~cm}^{-1}$ (Fig. 5(b)), implying peptides might be partly oxidized. The hydrogen bonds formed by hydroxyl groups might promote the assembly between peptide monomers. The vibrations of the amide I band are remarkably enhanced at $1644 \mathrm{~cm}^{-1}$ in a wide range between 1572 and 1800 $\mathrm{cm}^{-1}$ (Fig. 5(b)). The wide-range peak was previously observed by other groups for freshly dissolved and lyophilized peptides, suggesting a presence of unordered and turn-like structures [43]. Therefore, the metal-peptide nanofilms have mostly unordered and turn-like structures. This result is due to the electron-induced assembly accomplished in few minutes, which is too fast to realize an ordered packing. Moreover, with increasing Pd concentration, the shoulder peak of turn-like structures is weaker and a slight enhancement at $1617 \mathrm{~cm}^{-1}$ is observed (Fig. 5(c)), suggesting the Pd-peptide interaction helps to form locally ordered structure around the metal NPs. It is interesting to note that unordered molecular-level microstructures develop to macroscopically ordered 2D structures, decorating with high density but highly dispersive metal NP. The ultra-rapid assembling rate and the limited rates of electron transfer and mass diffusion at the gas-liquid interface conflict intensely but finally realize the collaboration and complementation.

The composition of metal, $\mathrm{C}, \mathrm{O}$ and $\mathrm{N}$ atoms calculated from full XPS spectra is shown in Table S1. The 0 content increases from $12.5 \%$ to $18.1 \%-20.4 \%$ after the assembly, which confirms peptides are partly oxidized. The XPS spectra of $\mathrm{C} 1 \mathrm{~s}$ and $\mathrm{N} 1 s$ of KLVFF before and after electron-induced assembly are shown in Fig. 5(d)-(g). The N $1 s$ spectra of KLVFF powders show the un-protonated $-\mathrm{NH}_{2}$ peak of $399.3 \mathrm{eV}$ with a slight shoulder at $401.3 \mathrm{eV}$, assigned to protonated $-\mathrm{NH}_{3}{ }^{+}$. No obvious changes are observed after electron-induced assembly, indicating $\mathrm{N}$ groups are stable during the assembly. The $\mathrm{C} 1 \mathrm{~s}$ spectra of KLVFF powders show $\mathrm{C}-\mathrm{C}, \mathrm{C}-\mathrm{N}$ of $\mathrm{N}$ residues, $\mathrm{N}-\mathrm{C}=\mathrm{O}$ of amide groups, $\mathrm{O}-\mathrm{C}=\mathrm{O}$ of carboxyl groups at 284.6, 286.3, 287.5 and $288.7 \mathrm{eV}$, corresponding with peptide features [44]. After 

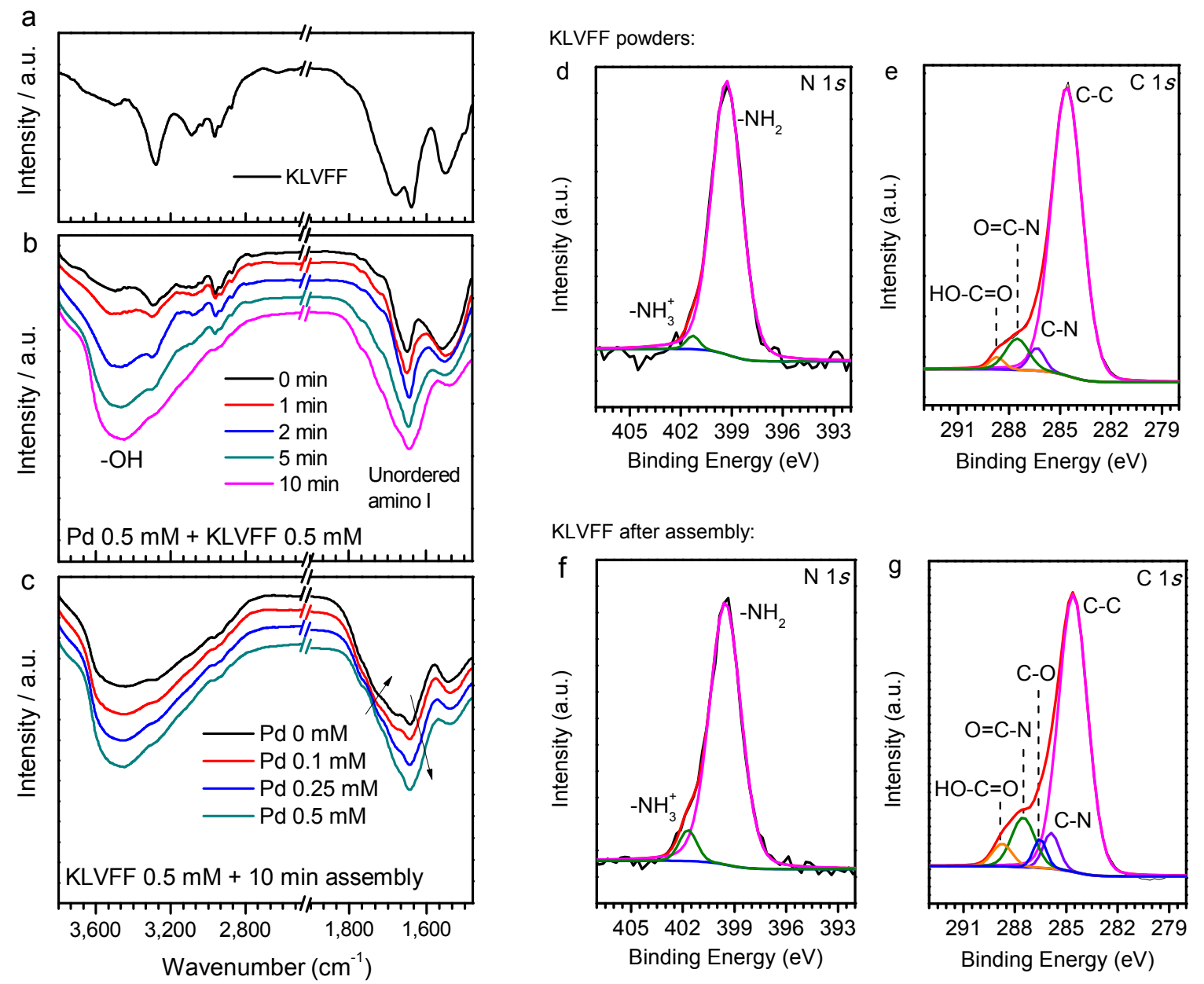

Fig. 5. The FTIR and XPS analysis of the electron-induced assembly process. The FTIR spectra of KLVFF powders (a) and Pd-P films (b,c) under different conditions; (b) change the Pd ion concentration from 0 to $0.5 \mathrm{mM}$; (c) change the reaction time from 0 to $10 \mathrm{~min}$; (d-g) The XPS spectra of KLVFF before and after assembly.

assembly, the $\mathrm{O}-\mathrm{C}=\mathrm{O}$ integral intensity at $288.7 \mathrm{eV}$ is $39 \%$ of $\mathrm{N}-\mathrm{C}=\mathrm{O}$ intensity, which is slightly higher than that of KLVFF powders $(25 \%)$. Since N-containing groups are stable, the integral area of $\mathrm{C}-\mathrm{N}$ peaks is kept $50 \%$ area of $\mathrm{N}-\mathrm{C}=\mathrm{O}$ in the fitting process. An extra peak appears at $286.5 \mathrm{eV}$ with $33 \%$ area of $\mathrm{N}-\mathrm{C}=\mathrm{O}$. This extra peak is well-matched to $\mathrm{C}-\mathrm{O}$ bonds in hydroxyl groups [45]. The number of $\mathrm{N}-\mathrm{C}=\mathrm{O}$ in one KLVFF molecule is 4 , while the extra $\mathrm{O}-\mathrm{C}=\mathrm{O}$ and $\mathrm{C}-\mathrm{O}$ groups are $14 \%$ and $33 \%$, respectively. This result reflects that averagely 0.56 $\mathrm{O}-\mathrm{C}=\mathrm{O}$ and and $1.32 \mathrm{C}-\mathrm{O}$ groups per KLVFF molecule are generated on the nanofilm surfaces.

XPS and FTIR analyses have shown the increase of hydroxyl groups in side chains. DFT study was then conducted to investigate the potential $\mathrm{C}-\mathrm{H}$ oxidation position and hydroxylation pathway. Before building calculation models, we first confirmed the $\mathrm{M}_{0}-\mathrm{P}_{0.5}$ still exhibits nanofilm structures (Fig. S7), indicating noble metals are not necessary for assembly. Therefore, we proposed to simulate the hydroxylation process without metal participation. This helps to simplify calculation and to avoid the complicated influences of catalytic effect of metal surfaces. Since the assembly occurs at the gas-liquid interface and the peptide molecules are nonvolatile, we simulated the
$\mathrm{C}-\mathrm{H}$ oxidation reaction takes place in water. The gas containing $\mathrm{Ar}$ atoms and gaseous $\mathrm{H}_{2} \mathrm{O}$ molecules is ionized to form glow-discharge plasma and provides abundant positive and negative species such as $\mathrm{Ar}^{+}, \mathrm{e}^{-}, \cdot \mathrm{H}$ and $\cdot \mathrm{OH}$ free radicals. Among them, the $\cdot \mathrm{OH}$ free radicals feasibly attack the $\mathrm{C}-\mathrm{H}$ bonds of KLVFF to form C-OH. A KLVFF molecule contains 27 $\mathrm{C}-\mathrm{H}$ positions, which can be divided into aromatic $\mathrm{Ar}-\mathrm{H}$ and aliphatic $\mathrm{CH}, \mathrm{CH}_{2}$ and $\mathrm{CH}_{3}$, shown in Fig. 6(a). We chose $\mathrm{C} 18$, C7, $\mathrm{C} 8$ and $\mathrm{C} 3$ to make a representative comparison of aromatic $\mathrm{Ar}-\mathrm{H}$ and aliphatic $\mathrm{CH}_{n}(n=1-3)$. All the calculations were performed using the $\mathrm{DMol}^{3}$ module in Material Studio (details see method section). The reaction path for the formation of $\mathrm{C}-\mathrm{OH}$ from $\mathrm{C}-\mathrm{H}$ was explored. Two possible routes are described as following: (1) single $\mathrm{OH}$ radical route (S route, Fig. 6(b)); (2) double $\mathrm{OH}$ radical route (D route, Fig. 6(c)). The $\mathrm{OH}$ free radicals have strong $\mathrm{CH} \cdots \mathrm{OH}$ interaction (12.11-16.14 $\mathrm{kcal} \mathrm{mol}^{-1}$ ) forming the initial complex, IC. The $\mathrm{H}$ of $\mathrm{C}-\mathrm{H}$ is $2.57,2.44,2.73$, $2.29 \AA$ from $\mathrm{OH}$ for $\mathrm{C} 7, \mathrm{C} 3, \mathrm{C} 8$ and C18, respectively. Both $\mathrm{OH}$ radical routes start with $\mathrm{H}$-abstraction step (IC to TS1 to INT). The $\mathrm{H}$ of $\mathrm{C}-\mathrm{H}$ is transferred to $\mathrm{OH}$ and undergoes the transition state, TS1. In the H-abstraction step, the TS1 located above IC shows energy barriers of $0.94,9.12,10.51$ and $7.24 \mathrm{kcal} \mathrm{mol}^{-1}$ 
a<smiles>CC(C)C[C@H](NC(=O)[C@H](N)CCCC(C)N)C(=O)N[C@@H](C(=O)O)C(=O)N[C@@H](Cc1ccccc1)C(=O)N[C@@H](Cc1ccccc1)C(=O)O</smiles>

Armatic Ar-H: $16,17,18,19,20,23,24,25,26,27$

Aliphatic $\mathrm{CH}: 5,7,10,11,14,21$

Aliphatic $\mathrm{CH}_{2}: 1,2,3,4,6,15,22$

Aliphatic $\mathrm{CH}_{3}: 8,9,12,13$

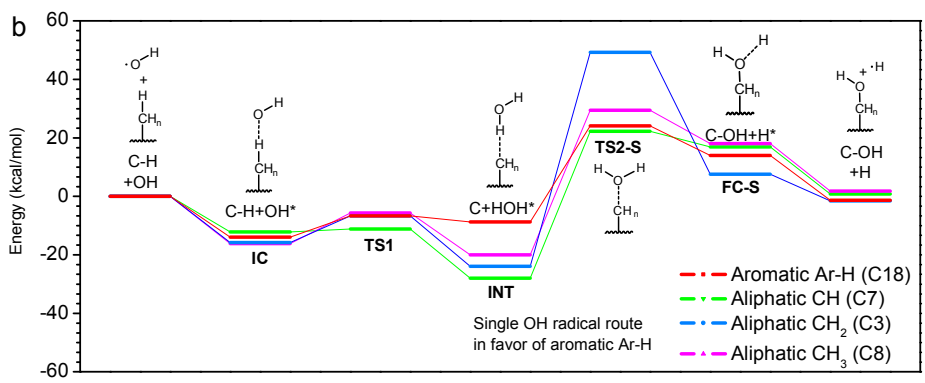

d

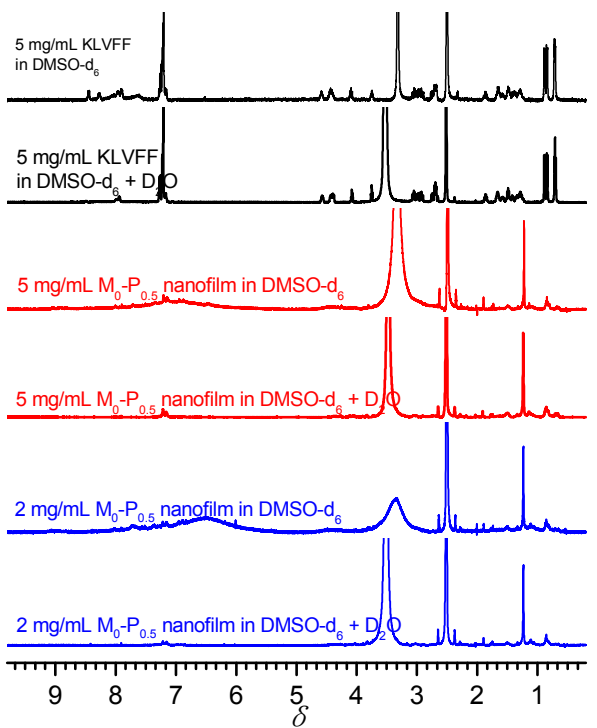

Fig. 6. The DFT calculatation of the C-H hydroxylation process and ${ }^{1} \mathrm{H}-\mathrm{NMR}$ results of KLVFF peptide before and after the electron-induced assembly. (a) The classify of $\mathrm{C}-\mathrm{H}$ bonds in $\mathrm{KLVFF}$ molecule; Potential energy surface of $\mathrm{C}-\mathrm{H}$ hydroxylation to $\mathrm{C}-\mathrm{OH}$ through single $\mathrm{OH}$ radical $\mathrm{S}$ route (b) and double OH radical D route (c). IC, initial complex; TS1, transition state for H-abstraction; TS2-S, transition state for HOH-rebound in S route; INT, intermediate; INT-D, intermediate in D route; FC-S and FC-D, final complex. (d) The ${ }^{1} \mathrm{H}-\mathrm{NMR}$ results of KLVFF peptide and $\mathrm{M}_{0}-\mathrm{P}_{0.5}$ nanofilms tested in DMSO- $\mathrm{d}_{6}$ with and without $\mathrm{D}_{2} \mathrm{O}$.

for C7, C3, C8 and C18, respectively. Then intermediates INT are formed with $\mathrm{C} \cdots \mathrm{HOH}$ interaction. The bond length $(d(\mathrm{C} \cdots \mathrm{H})$ $=1.95,1.71,1.89$ and 1.75 for $\mathrm{C} 7, \mathrm{C} 3, \mathrm{C} 8$ and $\mathrm{C} 18$ ) results in a $\mathrm{H}_{2} \mathrm{O}$ molecule weakly adsorbed at the $\mathrm{H}$ vacancy.

Then the INT evolves to single and double $\mathrm{OH}$ radical routes. In $\mathrm{S}$ route, the INT undergoes $\mathrm{HOH}-$ rebound to form final complex, FC. The transition state of the rebound step shows obvious difference between aromatic and aliphatic $\mathrm{C}-\mathrm{H}$ bonds. The energy barrier is $32.84 \mathrm{kcal} \mathrm{mol}^{-1}$ for aromatic Ar-H (C18), which is much lower than 50.22 (C7), 73.16 (C3) and 49.43 (C8) $\mathrm{kcal} \mathrm{mol}^{-1}$ of aliphatic $\mathrm{C}-\mathrm{H}$. During this step, the $\mathrm{C} \cdots \mathrm{HOH}$ interaction is rebounded to $\mathrm{C} \cdots \mathrm{OH}_{2}$ and further forms $\mathrm{FC}$ of $\mathrm{C}-\mathrm{OH} \cdots \mathrm{H}$ interaction. Compared with the $\mathrm{H}$-abstraction step, the $\mathrm{HOH}-$ rebound step in S route possesses higher energy barriers and is regarded as the speed-limited step. The huge reaction barriers of aliphatic $\mathrm{CH}, \mathrm{CH}_{2}$ and $\mathrm{CH}_{3}$ suggest that it is tough to react in these three positions. Therefore, the $\mathrm{S}$ route is in favor of aromatic Ar-H (C18) with reaction barrier of 32.84 $\mathrm{kcal}^{\mathrm{mol}}{ }^{-1}$. The $\mathrm{S}$ route with a rebound step was previously reported in researches on $\mathrm{CH}$ activation on metal catalyst surfaces, including methane [46], ethane [47] acetonitrile [48] and methylbenzene [49]. In the catalyst-participated system, it is hard to generate and stabilize multiple $\mathrm{OH}$ free radicals at sin- gle metal site, thus, the rebound step is suggested to be necessary. However, the $\mathrm{OH}$ free radicals generated from water present abundantly in ionized gas during electron induction process. It provides the possibility of the double $\mathrm{OH}$ radical route detouring the rebound step. In D route, the INT with $\mathrm{C} \cdot \cdots \mathrm{HOH}$ interaction undergoes a step of $\mathrm{HOH}$-desorption to form intermediates, INT-D. An extra $\mathrm{OH}$ free radical replenishes the vacancy of INT-D to form FC-D. In D route of INT to INT-D to FC-D, the reaction only needs to overcome the $\mathrm{HOH}$-desorption step with lower energy barriers of 7.49, 7.23, 4.99 and $7.57 \mathrm{kcal}$ $\mathrm{mol}^{-1}$ for C7, C3, C8 and C18. For C7 and C18, the $\mathrm{HOH}$-desorption step is the speed-limited step with energy barriers of 7.49 and $7.57 \mathrm{kcal} \mathrm{mol}^{-1}$, respectively. For C3 and $\mathrm{C} 8$, the speed-limited step is $\mathrm{H}$-abstraction with energy barriers of 9.12 and $10.51 \mathrm{kcal} \mathrm{mol}^{-1}$, respectively. Therefore, the D route is in favor of aliphatic $\mathrm{CH}$ (C7) and aromatic $\mathrm{Ar}-\mathrm{H}$ (C18) with lower energy barriers. Compared the energy barriers of $\mathrm{S}$ and $\mathrm{D}$ routes, the latter is much lower than the former. However, it is unable to conclude the hydroxylation reaction follows the $\mathrm{D}$ route, which needs a second time of the $\cdot \mathrm{OH}$ generation and collision. During the extremely fast assembly under high energy electron environment, it is hard to affirm the reaction route is limited to collision probability or energy requirement. 
Combining the DFT results of both routes, the hydroxylation reaction is in favor of aromatic Ar-H (S and D routes) and aliphatic $\mathrm{CH}$ (D route).

In order to confirm the results of DFT study, the ${ }^{1} \mathrm{H}-\mathrm{NMR}$ spectra of KLVFF peptide before and after electron induction process were tested (Fig. 6(d)). The ${ }^{1} \mathrm{H}-\mathrm{NMR}$ spectra of KLVFF in DMSO- $\mathrm{d}_{6}$ are accorded with the previous work [41] $(\delta): 0.71$ [2d, 6H, $2 \times \mathrm{CH}_{3}$ (Val)], 0.86 [2d, 6H, $2 \times \mathrm{CH}_{3}$ (Leu)], 1.20-1.70 [m, 9H, $4 \times \mathrm{CH}_{2}$ (Lys, Leu), CH (Leu)], 1.85 [m, 1H, CH (Val)], 2.65-2.78 [m, 2H, CH 2 (Lys)], 2.87-3.10 [m, 4H, $2 \times \mathrm{CH}_{2}$ (Phe)], $3.75[\mathrm{~m}, 1 \mathrm{H}, \mathrm{CH}(\alpha)(\mathrm{Lys})], 4.09$ [dd, 1H, CH( $\alpha)(\mathrm{Val})], 4.43[\mathrm{~m}$, $2 \mathrm{H}, \mathrm{CH}(\alpha)$ (Phe)], 4.59 [m, 1H, $\mathrm{CH}(\alpha)$ (Leu)], 7.12-7.30 [m, 10H, Ar-H (Phe)], 7.65 [s, 2H, NH 2 (Lys)], 7.91 [d, 1H, NH (Val)], 7.97 [d, 1H, NH (Phe)], 8.05 [s, 2H, NH 2 (Lys)], 8.26 [d, 1H, NH (Phe)], 8.43 [d, 1H, NH (Leu)]. After electron induced assembly, the KLVFF forms $\mathrm{M}_{0}-\mathrm{P}_{0.5}$ nanofilms with several changes in NMR spectra. Primarily, the $\mathrm{H}$ amount in $\mathrm{CH}$ region $(\delta=$ 1.8-4.8) and $\mathrm{Ar}-\mathrm{H}$ area ( $\delta=7.1-7.3)$ decreases, suggesting these $\mathrm{H}$ atoms may be partly reacted. The peak located at $\delta=$ 3.4 becomes broader than KLVFF in DMSO- $\mathrm{D}_{6}$ and returns to narrow after $\mathrm{D}_{2} \mathrm{O}$ exchanging, suggesting the formation of aliphatic hydroxyl groups. An extra broad peak appears at $\delta=$ 6.5-7.5 under $5 \mathrm{mg} \mathrm{mL}^{-1}$ DMSO-D $_{6}$ and shifts to $\delta=6-7$ under lower concentration of $2 \mathrm{mg} \mathrm{mL}^{-1}$. This broad peak disappears after $\mathrm{D}_{2} \mathrm{O}$ exchanging. The above phenomenon suggests this broad peak is assigned to aromatic hydroxyl groups. The shift of the peak is because the decrease of $\mathrm{Ar}-\mathrm{OH}$ concentration also reduces the intermolecular hydrogen bonding of phenolic compounds, which leads a lower chemical shift. As for aliphatic $\mathrm{CH}_{3}$, their NMR peak remains strong; while the $2 \mathrm{~d} \mathrm{CH}_{3}$ peaks of $\delta=0.71$ and 0.86 shift to single peak of $\delta=1.23$, indicating a structural evolution from original $-\mathrm{CH}-\left(\mathrm{CH}_{3}\right)_{2}$ to $-\mathrm{C}(\mathrm{OH})-\left(\mathrm{CH}_{3}\right)_{2}$. This result proves the $\mathrm{CH}_{3}$ is relatively stable compared with adjacent $\mathrm{CH}$. The above NMR results confirm the DFT conclusion that the hydroxylation reaction is in favor of aromatic Ar-H (S and D routes) and aliphatic $\mathrm{CH}$ (D route).

Molecular weights of peptides in $\mathrm{Pd}_{0.5}-\mathrm{P}_{0.5}$ films dissolved in hexafluoroisopropanol (HFIP) were verified by MALDI-ToF mass spectrometry, showing mainly original $\mathrm{m} / \mathrm{z}$ of $[\mathrm{M}+\mathrm{H}]^{+}=$ 653.6. The HFIP is only able to break the weak interaction, such as hydrogen bonds, and frequently used for preventing or destroying assembling [50]. No molecules were detected between $\mathrm{m} / \mathrm{z}$ of $1000-5000$, suggesting the assembly comes from weak interactions rather than polymerizations linked by strongly covalent bonds (Fig. S8). Moreover, the aromatic (FF) side chains play an important role in supramolecular assembly. When KLVFF is replaced by the dipeptide FF, the products are still nanofilms. However, when changed to GGG without side chains, the assembled morphology changes to clusters (Fig. S9). The results demonstrate the electron-induced assembly strategy can realize different morphologies. The side chains of the peptide have an important role on the morphological control, and the $\pi-\pi$ stacking of aromatic rings contributes to $2 \mathrm{D}$ film-shaped structure.

After the above investigation on peptide functional groups, we clarify the intermolecular interactions of metal-peptide nanofilms can be divided into three kinds: (1) the binding of metal NPs and carboxylic groups related to the metal-peptide interaction; (2) the inherent hydrogen bonding formed by amides of the peptide backbone; (3) the extra hydrogen bonding formed by oxygen-containing groups in oxidized side chains. The structure construction of the metal-peptide nanofilms can be summarized as Fig. 7. Metal ions and peptide are dissolved in water. Electron-induced assembly occurs at the gas-liquid interface when the Ar gas in the headspace is ionized. On one hand, Pd ions are reduced to Pd NPs by electrons and encapsulated in peptides. On the other hand, generated hydroxyl groups and hydrogen bonds promote peptides to quickly assemble into random and unordered structures. The assembly of metal NPs and peptides develops to form disc-shaped building blocks. The rapid crosslinking decreases the solubility of peptides, which forces the assembled building blocks to precipitate and accumulate at the gas-liquid interfaces. The $\pi-\pi$ stacking of aromatic rings in side chains guides the accumulation to form free-standing 2D nanofilms at the gas-liquid interfaces. After freeze-drying, the 2D nanofilms can form ultralight flocculent 3D networks.

\subsection{Responsive release of metal NPs for catalytic reduction of 4-nitrophenol}

The metal-peptide nanofilms can realize the stable storage of metal NPs for the long term. The TEM of $\mathrm{Pd}_{0.5}-\mathrm{P}_{0.5}$ nanofilms stored in water at neutral $\mathrm{pH}$ and room temperature for three months are shown in Fig. S10. The size of Pd NPs was $2.0 \pm 0.3$ $\mathrm{nm}$ with a little increase, compared to the originally $1.8 \pm 0.2$ nm. The $\mathrm{Pd}_{0.5}-\mathrm{P}_{0.5}$ nanofilms $(1 \mathrm{mg}$ ) still show no color changes in solution after 365-days room-temperature storage (Fig. 6). When added $\mathrm{NaBH}_{4}(0.05 \mathrm{mM})$, the $\mathrm{Pd}_{0.5}-\mathrm{P}_{0.5}$ nanofilms are quickly dissolved and the color of the solution changes to brown (Fig. 7). The alkaline $\mathrm{NaBH}_{4}$ promotes the ionization of $-\mathrm{COOH}$ and dissolution of peptides, so to realize a quickly responsive release of Pd NPs. The surface oxide layers of Pd NPs are reduced to $\mathrm{Pd}^{0}$, resulting in the change of color to brown. The size of Pd NPs is increased to $2.6 \pm 0.4 \mathrm{~nm}$ (Fig. S11). When added glutathione (GSH, $5 \mathrm{mM}$ ), the $\mathrm{Pd}_{0.5}-\mathrm{P}_{0.5}$ nanofilms are gradually dissolved and the solution slowly changes to yellow. The GSH was a weakly acidic and reductive reagent, which is able to gradually break the interaction of Pd-KLVFF to realize a slow release of Pd NPs. The reductive GSH cannot reduce the surface oxide layers but strongly bond with Pd NPs to form GS-Pd NPs. The solution color is still yellow. The slowly responsive release of metal NPs can be potentially applied for the drug control release, photothermal therapy and other imaging or sensing applications. In this work, we successfully used the fast released $\mathrm{Pd}, \mathrm{Pt}$ and $\mathrm{Au}$ NPs to catalyze the reduction of 4-nitrophenol.

The catalyst solutions containing Pd, Pt and Au NPs were prepared after the responsive release of metal NPs from metal-peptide nanofilms under $\mathrm{NaBH}_{4}$. The released metal NPs were tested for catalytic reduction of 4-nitrophenol by $\mathrm{NaBH}_{4}$ in water. The reaction does not proceed without a catalyst but proceeds rapidly in the presence of released metal NPs. The absorption peak of 4-nitrophenol aqueous solution shows a 


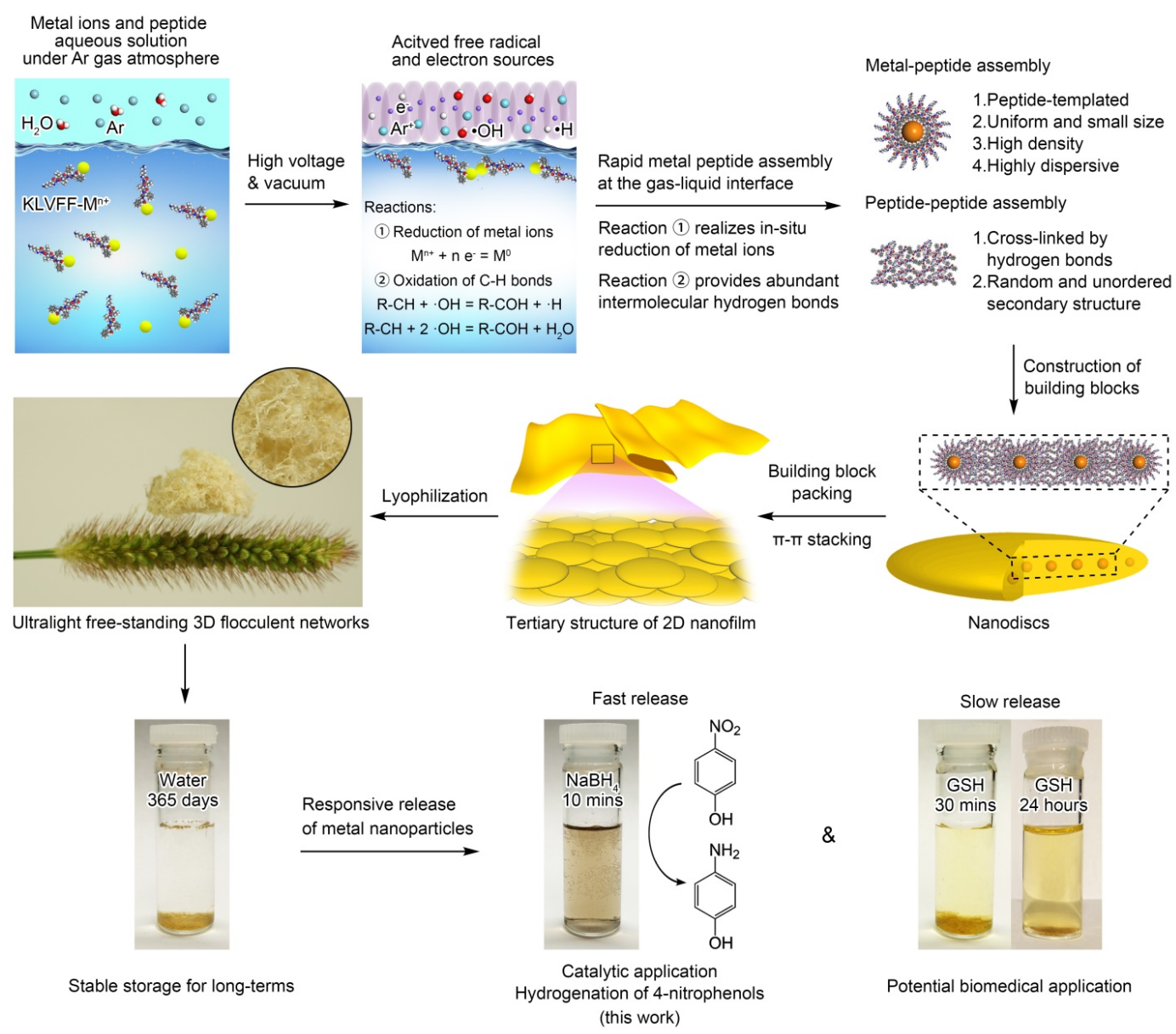

Fig. 7. Schematic illustration of the electron-induced assembly, long-term storage of metal-peptide nanofilms and their responsive release under $\mathrm{NaBH}_{4}$ and glutathione (GSH) conditions.

stable characteristic peak at $400 \mathrm{~nm}$ when mixed with $\mathrm{NaBH}_{4}$. After the addition of the catalyst solution, the absorbance of 4-nitrophenol at $400 \mathrm{~nm}$ gradually decreases as the reaction proceeds (Fig. 8). The linear relationship between $\ln \left(C_{\mathrm{t}} / C_{0}\right)$ and reaction time $(t)$ confirms the pseudo-first-order kinetics. Based on $\ln \left(C_{\mathrm{t}} / C_{0}\right)=k_{\text {app }}$, the rate constant $k_{\text {app }}$ of Pd, Pt and $\mathrm{Au}$ NPs stabilized by peptides were calculated to be $5.37 \times 10^{-3}$, $9.28 \times 10^{-4}$ and $5.12 \times 10^{-3} \mathrm{~s}^{-1}$, respectively, from the slope of the straight line. The Pd and Au NPs show similar $k_{\text {app }}$ value, which is much higher than Pt. This comparison is under same metal amount of $5 \mathrm{~mol} \%$. In addition, peptide-stabilized metal NPs show high efficiencies in the comprehensive comparisons of some previously reported noble-metal catalysts (Table S2) $[51,52]$. In summary, our electron-induced assembly strategy is able to synthesize supramolecular noble-metal materials and responsively release metal NPs for catalytic reduction of 4-nitrophenol with superior activity.

\section{Conclusions}

In this work, we demonstrate that electron-induced assembly can be used to construct free-standing supramolecular nanofilms encapsulating uniform metal NPs with similar small diameters. Importantly, we investigate the assembly mecha- nism and reveal the level-by-level assembly process: from monomers to disc-shaped building blocks, further to films. The binding of metal NPs and carboxylic groups relate to the metal-peptide interaction, contributing to the stabilization of metal NPs. The hydrogen bonding formed by the amide bonds of the peptide backbone and hydroxyl groups of the oxidized side chains result in the rapid crosslinking of peptide monomers and promote a quick assembly of random and unordered structures. The side chains of the peptides have an important role on the fast cross-linking and morphological control, and the $\pi-\pi$ stacking of aromatic rings contributes to $2 \mathrm{D}$ film-shaped structure. Remarkably, the responsive releases of metal NPs from metal-peptide nanofilms are firstly reported. Quick and slow releases can be realized by the addition of $\mathrm{NaBH}_{4}$ and glutathione, respectively. The released Pd, Pt and $\mathrm{Au}$ NPs successfully catalyzed the reduction of 4-nitrophenol with superior activity. We believe that this work has a prospective guiding significance for the purposeful design of supramolecular materials. The responsive release of metal NPs can be potentially applied for the drug control release, photothermal therapy, imaging and sensing, template removal and many other applications. The present study would lead to a development of an excellent alternative to polymer stabilized metal nanoparticle, which has a difficulty in the removal of the poly- 

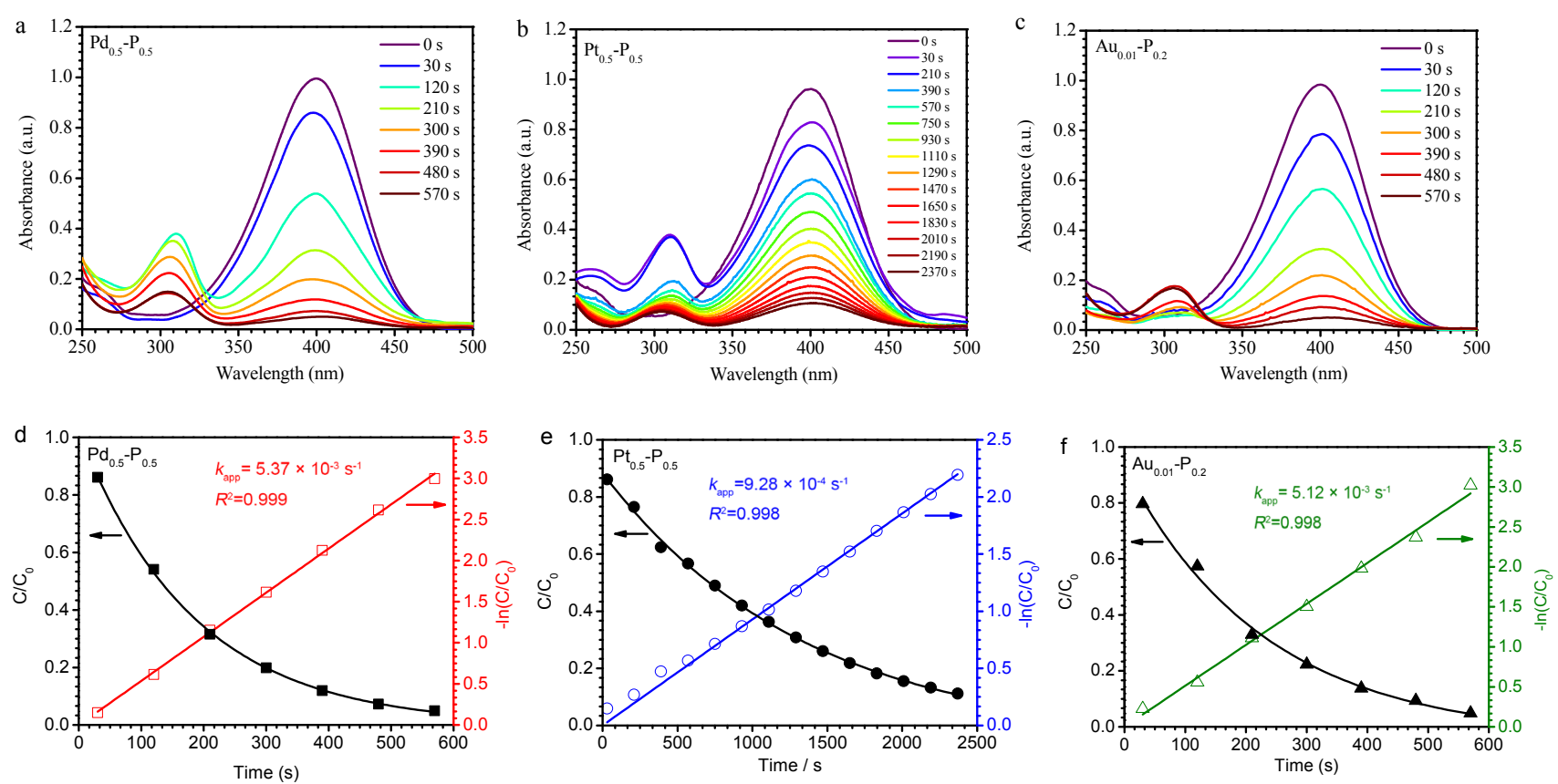

Fig. 8. Catalytic performance of noble-metal-peptide nanofilms. UV-vis absorption spectra and the plot of $C / C_{0}(\mathrm{a}, \mathrm{c}, \mathrm{e})$ and $\ln \left(C / C_{0}\right)(\mathrm{b}, \mathrm{d}, \mathrm{f})$ versus reaction time during the catalytic reduction of 4-NP over $\mathrm{NaBH}_{4}$ treated $\mathrm{Pd}_{0.5}-\mathrm{P}_{0.5}(\mathrm{a}, \mathrm{d}), \mathrm{Pt}_{0.5}-\mathrm{P}_{0.5}$ (b,e) and $\mathrm{Au}_{0.01}-\mathrm{P}_{0.2}$ (c,f) samples. Initial curves at $0 \mathrm{~s}$ were obtained by adding $\mathrm{NaBH}_{4}$ into 4-NP solution.

mer template [53].

\section{Supporting Information.}

The additional TEM images, XPS full spectra, TGA-DSC curves and MALDI-ToF spectra of the metal-peptide nanofilms; the photos, SEM and TEM images of $\mathrm{Pd}_{2} \mathrm{FF}_{1}$ and $\mathrm{Pd}_{0.5} \mathrm{GGG}_{0.5}$, schematic illustration of the reactor.

\section{Acknowledgment}

We acknowledge the financial support from the National Natural Science Foundation of China (21621004 and 21536008). Zongyuan Wang acknowledges the financial support from the China Scholarship Council (201706250085). We thank the JHU Department of Chemistry Mass Spectrometry for the use of the MALDI-TOF instrument. We thank Hao Wang for her help in the use of English.

\section{Notes}

The authors declare no competing financial interest.

\section{References}

[1] K. Sato, M. P. Hendricks, L. C. Palmer, S. I. Stupp, Chem. Soc. Rev., 2018, 47, 7539-7551.

[2] L. L. Lock, Y. Li, X. Mao, H. Chen, V. Staedtke, R. Bai, W. Ma, R. Lin, Y. Li, G. Liu, H. Cui, ACS Nano, 2017, 11, 797-805.

[3] A. S. Weingarten, R. V. Kazantsev, L. C. Palmer, M. McClendon, A. R. Koltonow, A. P. S. Samuel, D. J. Kiebala, M. R. Wasielewski, S. I. Stupp, Nat. Chem., 2014, 6, 964-970.
[4] A. Z. Khan, M. Bilal, T. Rasheed, H. M. N. Iqbal, Chin. J. Catal., 2018, 39, 1861-1868.

[5] N. Wang, H. Zheng, W. Zhang, R. Cao, Chin. J. Catal., 2018, 39, 228-244.

[6] Y. Li, L. L. Lock, Y. Wang, S.-H. Ou, D. Stern, A. Schön, E. Freire, X. Xu, S. Ghose, Z. J. Li, H. Cui, Biomaterials, 2018, 178, 448-457.

[7] C. F. Anderson, R. W. Chakroun, H. Su, R. E. Mitrut, H. Cui, ACS Nano, 2019, 13, 12957-12968.

[8] E. Pazos, E. Sleep, C. M. Rubert Pérez, S. S. Lee, F. Tantakitti, S. I. Stupp, J. Am. Chem. Soc., 2016, 138, 5507-5510.

[9] A. Ghorbani-Choghamarani, Z. Taherinia, Chin. J. Catal., 2017, 38, 469-474.

[10] F. S. Han, M. Higuchi, D. G. Kurth, Adv. Mater., 2007, 19, 3928-3931.

[11] G. Nyström, M. P. Fernández-Ronco, S. Bolisetty, M. Mazzotti, R. Mezzenga, Adv. Mater., 2016, 28, 472-478.

[12] R. Xing, K. Liu, T. Jiao, N. Zhang, K. Ma, R. Zhang, Q. Zou, G. Ma, X. Yan, Adv. Mater., 2016, 28, 3669-3676.

[13] V. Kunz, D. Schmidt, M. I. S. Roehr, R. Mitric, F. Wuerthner, Adv. Energy Mater., 2017, 7, 1602939.

[14] B. Yang, X. Jiang, Q. Guo, T. Lei, L.-P. Zhang, B. Chen, C.-H. Tung, L.-Z. Wu, Angew. Chem. Int. Ed., 2016, 55, 6229-6234.

[15] J. Z. Zheng, Y. J. Wu, K. Deng, M. He, L. C. He, J. Cao, X. G. Zhang, Y. L. Liu, S. X. Li, Z. Y. Tang, ACS Nano, 2016, 10, 8564-8570.

[16] Z. Sun, F. Lv, L. Cao, L. Liu, Y. Zhang, Z. Lu, Angew. Chem. Int. Ed., 2015, 54, 7944-7948.

[17] B. Ma, Y. Wu, S. Zhang, S. Wang, J. Qiu, L. Zhao, D. Guo, J. Duan, Y. Sang, L. Li, ACS Nano, 2017, 11, 1973-1981.

[18] H. Hu, Q. Yan, R. Ge, Y. Gao, Chin. J. Catal., 2018, 39, 1167-1179.

[19] M. Cong, D. Sun, L. Zhang, X. Ding, Chin. J. Catal., 2020, 41, 242-248.

[20] R. Misra, A. Saseendran, S. Dey, H. N. Gopi, Angew. Chem. Int. Ed., 2019, 58, 2251-2255.

[21] J. Navarro-Sánchez, A. I. Argente-García, Y. Moliner-Martínez, D. 
Roca-Sanjuán, D. Antypov, P. Campíns-Falcó, M. J. Rosseinsky, C. Martí-Gastaldo, J. Am. Chem. Soc., 2017, 139, 4294-4297.

[22] H. Su, W. Zhang, H. Wang, F. Wang, H. Cui, J. Am. Chem. Soc., 2019, 141, 11997-12004.

[23] W. Wang, Z. Wang, M. Yang, C.-J. Zhong, C.-J. Liu, Nano Energy, 2016, 25, 26-33.

[24] W. Wang, C. F. Anderson, Z. Wang, W. Wu, H. Cui, C.-J. Liu, Chem. Sci., 2017, 8, 3310-3324.

[25] J. Yan, Y. Pan, A. G. Cheetham, Y.-A. Lin, W. Wang, H. Cui, C.-J. Liu, Langmuir, 2013, 29, 16051-16057.

[26] Y.-X. Pan, H.-P. Cong, Y.-L. Men, S. Xin, Z.-Q. Sun, C.-J. Liu, S.-H. Yu, ACS Nano, 2015, 9, 11258-11265.

[27] Y.-x. Pan, C.-j. Liu, S. Zhang, Y. Yu, M. Dong, Chem. Eur. J., 2012, 18, 14614-14617.

[28] N. Rui, Z. Wang, K. Sun, J. Ye, Q. Ge, C.-j. Liu, Appl. Catal. B, 2017, 218, 488-497.

[29] B. Delley, J. Chem. Phys., 1990, 92, 508-517.

[30] B. Delley, J. Chem. Phys., 2000, 113, 7756-7764.

[31] B. Delley, J. Chem. Phys., 1991, 94, 7245-7250.

[32] W.-l. Chen, W.-X. Chen, G.-l. Zhuang, J. Zheng, L. Tan, X. Zhong, J.-g. Wang, CrystEngComm, 2013, 15, 5545-5551.

[33] X. Zhu, C. Jin, X.-S. Li, J.-L. Liu, Z.-G. Sun, C. Shi, X. Li, A.-M. Zhu, ACS Catal., 2017, 7, 6514-6524.

[34] B. Zhu, X.-S. Li, P. Sun, J.-L. Liu, X.-Y. Ma, X. Zhu, A.-M. Zhu, Chin. J. Catal., 2017, 38, 1759-1769.

[35] L. Di, D. Duan, Z. Zhan, X. Zhang, Adv. Mater. Interfaces, 2016, 3, 1600760.1-1600760.5.

[36] L. Di, Z. Li, X. Zhang, H. Wang, Z. Fan, Catal. Today, 2019, 337, 55-62.
[37] Z.-G. Sun, X.-S. Li, J.-L. Liu, Y.-C. Li, B. Zhu, A.-M. Zhu, J. Catal., 2019, 375, 380-388.

[38] X. Zhu, J.-H. Liu, X.-S. Li, J.-L. Liu, X. Qu, A.-M. Zhu, J. Energy Chem., 2017, 26, 488-493.

[39] J. Zhang, H. Wang, Q. Zhao, L. Di, X. Zhang, Int. J. Hydrogen Energy, 2020, 45, 9624-9634.

[40] B. Qi, L. Di, W. Xu, X. Zhang, J. Mater. Chem. A, 2014, 2, 11885-11890.

[41] M. J. Krysmann, V. Castelletto, A. Kelarakis, I. W. Hamley, R. A. Hule, D. J. Pochan, Biochemistry, 2008, 47, 4597-4605.

[42] M. Jackson, H. H. Mantsch, Crit. Rev. Biochem. Mol. Biol., 1995, 30, 95-120.

[43] J. Seo, W. Hoffmann, S. Warnke, X. Huang, S. Gewinner, W. Schöllkopf, M. T. Bowers, G. von Helden, K. Pagel, Nat. Chem., 2016, 9, 39-44.

[44] R. Gao, L. Pan, Z. Li, X. Zhang, L. Wang, J.-J. Zou, Chin. J. Catal., 2018, 39, 664-672.

[45] L. Q. Xu, W. J. Yang, K.-G. Neoh, E.-T. Kang, G. D. Fu, Macromolecules, 2010, 43, 8336-8339.

[46] K. Yoshizawa, Y. Shiota, J. Am. Chem. Soc., 2006, 128, 9873-9881.

[47] P. Verma, K. D. Vogiatzis, N. Planas, J. Borycz, D. J. Xiao, J. R. Long, L. Gagliardi, D. G. Truhlar, J. Am. Chem. Soc., 2015, 137, 5770-5781.

[48] A. Bassan, M. R. A. Blomberg, P. E. M. Siegbahn, L. Que Jr, Chem. Eur. J., 2005, 11, 692-705.

[49] D. Balcells, C. Raynaud, R. H. Crabtree, O. Eisenstein, Chem. Commun., 2008, 744-746.

[50] Y. Hu, R. Lin, P. Zhang, J. Fern, A. G. Cheetham, K. Patel, R. Schulman, C. Kan, H. Cui, ACS Nano, 2016, 10, 880-888.

\section{Graphical Abstract}

Chin. J. Catal., 2021, 42: 376-387 doi: 10.1016/S1872-2067(20)63655-5

Electron-induced rapid crosslinking in supramolecular metal-peptide assembly and chemically responsive disaggregation for catalytic application

Zongyuan Wang, Jiajun Wang, Zeyu Sun, Wenlong Xiang, Chenyang Shen, Ning Rui, Mingzhu Ding, Yingjin Yuan, Honggang Cui *, Chang-jun Liu*

Tianjin University, China; The Johns Hopkins University, United States

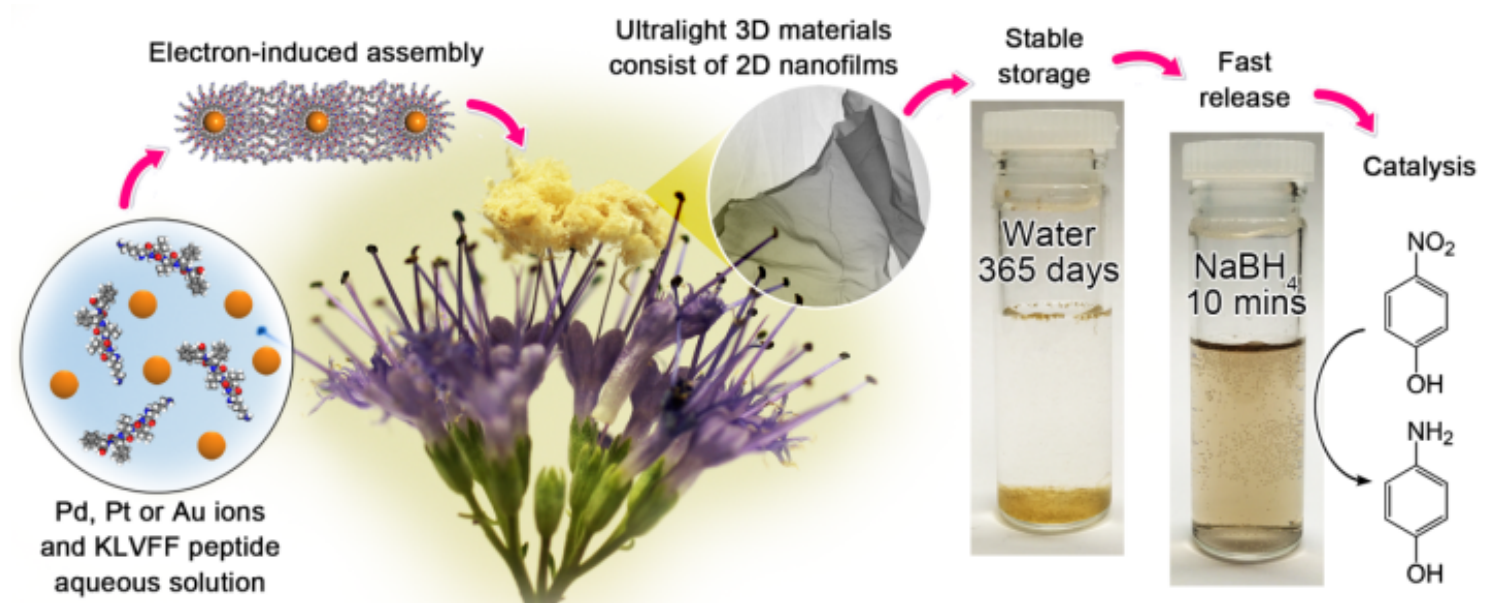

Mechanism study, responsive release and catalytic activity of Pd, Pt and Au@KLVFF nanofilms enabled by electron-induced assembly. 
[51] E. Kan, L. Kuai, W. Wang, B. Geng, Chem.-Eur. J., 2015, 21, 13291-13296.

[52] C. Wang, R. Ciganda, L. Salmon, D. Gregurec, J. Irigoyen, S. Moya, J.
Ruiz, D. Astruc, Angew. Chem. Int. Ed., 2016, 55, 3091-3095.

[53] Y. Tan, H. Liu, X.Y. Liu, A. Wang, C. Liu, T. Zhang, Chin. J. Catal., 2018, 39, 929-936.

\title{
电子诱导金属多肽的超分子组装、化学响应释放及其催化应用
}

\author{
王宗元 ${ }^{\mathrm{a}, \mathrm{b}}$, 王嘉骏 ${ }^{\mathrm{a}}$, 孙泽宇 ${ }^{\mathrm{a}}$, 项文龙 ${ }^{\mathrm{a}}$, 沈辰阳 ${ }^{\mathrm{a}}$, 芮 宁 ${ }^{\mathrm{a}}$, 丁明珠 ${ }^{\mathrm{a}}$, 元英进 ${ }^{\mathrm{a}}$, \\ 崔宏刚b,c,d, \#, 刘昌俊a, \\ ${ }^{a}$ 天津大学化工学院化工科学与工程协同创新中心, 天津 300072 , 中国 \\ b约翰霍普金斯大学化学与生物分子工程系和纳米生物技术研究所, 马里兰州21218, 美国 \\ c约翰霍普金斯大学药学院威尔默眼科研究所纳米医学中心, 马里兰州 21218 , 美国 \\ d约翰霍普金斯大学药学院肿瘤科和西德尼・坎摩尔综合癌症中心, 马里兰州21218, 美国
}

\begin{abstract}
摘要: 近年来, 超分子组装在催化、制药、传感器、提纯、组织工程等领域获得广泛应用. 为了实现超分子结构功能化, 经 常会将金属纳米颗粒或者金属活性位引入或共组装至有机超分子骨架中, 由此获得金属化的纳米材料. 例如, 金属纳米颗 粒修饰的多肽纤维、金属聚合物、金属负载的水凝胶和气凝胶. 常见的金属化策略包括自组织、金属有机配位络合、聚 合和电子诱导组装等. 其中, 由本课题组发展的电子诱导组装法已经被用于制备高效金属多肽催化剂、能源转化材料和非 均相催化剂模板等. 室温电子诱导组装利用了辉光等离子体富含的电子, 是室温电子还原制备纳米金属颗粒及相关催化 剂的进一步发展. 该方法操作过程简单, 仅需一步即可同时实现金属还原和有机物组装; 且绿色环保、不需要添加还原剂、 操作条件温和、反应时间短 (在室温条件下几分钟内即可反应完全). 所获得的二维多肽纳米薄膜含有高度分散的金属纳米 颗粒. 研究表明, 电子诱导组装法是构建超分子催化剂强有力的工具. 然而, 电子诱导超分子组装的反应机理仍然不清楚. 为了进一步开发应用新的超分子材料, 开展电子诱导组装机理研究十分必要.

本文选择 $\beta$ 淀粉肽的五肽片段作为电子诱导组装的单体和贵金属 $(\mathrm{Pd}, \mathrm{Pt}$ 和 $\mathrm{Au})$ 离子通过电子还原得到金属多肽纳米膜. 通过调控原料配比和浓度, 获得了包覆有超细贵金属纳米颗粒 (1-2 nm) 的金属多肽纳米薄膜. 通过扫描电子显微镜、透射 电子显微镜、X射线衍射光谱、X射线光电能谱等表征手段, 对金属多肽纳米薄膜的结构和成分进行了分析. 通过原子力显 微镜对金属多肽纳米薄膜的多级结构进行分析发现, 电子诱导组装的组装单元为碟状组合体, 与常规自组装有显著区别, 通过傅里叶变换红外光谱、X射线光电能谱等表征方法, 结合密度泛函(DFT)计算, 对组装过程多肽分子的表面性质和变化 进行了分析. 发现多肽在电子诱导组装过程中会发生部分氧化. DFT研究给出两种可能的羟基自由基活化碳氢键过程, 说 明形成的羟基提供了额外的氢键相互作用, 促进了组装的快速发生. 多肽中含有苯环的侧链对多肽组装后二维结构的形 成起到重要作用. 本文还首次发现金属多肽薄膜能够在化学试剂刺激下响应释放金属纳米颗粒. 如在硼氢化钠作用下可 以快速释放金属纳米颗粒、在谷胱甘肽作用下可以缓慢释放金属纳米颗粒. 嗍氢化钠作用下释放后的金属颗粒对4-氨基苯 酚还原反应具有良好的催化活性. 金属多肽薄膜的快速响应释放可以为稳定纳米金属颗粒提供一个新方法, 替代那些以 往采用的稳定剂难于脱除的纳米金属稳定方法. 而慢速响应释放则有潜力应用于药物缓释、光热治疗生物传感和成像等 医学领域.
\end{abstract}

关键词: 金属; 多肽; 组装; 响应释放; 还原; 催化剂

收稿日期: 2020-05-17. 接受日期: 2020-06-21. 出版日期: 2021-03-05.

*通讯联系人. 电话/传真: (022)27406490; 电子信箱: coronacj@tju.edu.cn

\#通讯联系人. 电子信箱: hcui6@jhu.edu

基金来源：国家自然科学基金(21621004, 21536008), 国家留学基金委(学号:201706250085).

本文的电子版全文由Elsevier出版社在ScienceDirect上出版(http://www.sciencedirect.com/science/journal/18722067). 